\title{
Preparing Teachers for Hybrid and Online Language Instruction
}

\author{
Merica McNeil \\ The University of Arizona
}

\begin{abstract}
Courses that are offered fully or partially online are becoming increasingly common for various reasons including needs for more flexibility and the affordances that technology can offer. One major challenge is that most of today's instructors did not learn online themselves and thus need to learn how to teach effectively using technology. This growing online trend is also true for language teaching, an area which demands special consideration due to its unique challenges: language teaching involves skill development and typically uses the target language as the medium of communication. Research has shown that teacher preparation and ongoing support are critical to the success of hybrid and online courses (Rubio \& Thoms, 2014a). This article provides a review of the literature on best practices in preparing and supporting those who teach a language in online or hybrid environments. Based on this, a model for professional development is proposed, which can be used and adapted by language program directors. Guidelines on developing these courses and supporting teachers as well as suggestions for further reading are provided.
\end{abstract}

Keywords: hybrid; online; teacher preparation; computer-assisted language learning

\section{Preparing Teachers for Hybrid and Online Language Instruction}

As the number of foreign language programs offering hybrid or online classes at beginning and intermediate levels continues to grow, the success of such courses often depends on teacher preparation and ongoing support (Rubio \& Thoms, 2014b). There has been considerable research in the field of teacher training for hybrid and online classes in general education, but only a limited amount of literature deals specifically with preparing instructors of a second or foreign language (henceforth, L2). This area merits special attention because the subject matter being taught, a language, is connected to skill development and communication (Hampel \& Stickler, 2005). In this article, best practices for preparing and supporting $L 2$ teachers based on the research literature will be presented. Based on this literature, a model for professional development, which could easily be adapted by language program directors for their local contexts, will be provided. Finally, the article will conclude with guidelines for developing courses that are fully or partially online and supporting teachers as well as offering suggestions for further reading. 


\section{Best Practices for Preparing L2 Instructors to Teach Hybrid or Online Courses}

There is no one-size-fits-all plan for professional development (Allen \& NegueruelaAzarola, 2010). Teachers hail from diverse backgrounds. In consequence, they possess different formal training, levels of pedagogical content knowledge, amounts of teaching experience, cultural beliefs, and theories about effective learning relationships. Language program directors, therefore, need to adapt training to meet the needs of instructors in their programs. At large public universities, for example, graduate students from a variety of fields usually teach most lower-level FL classes.

The research literature emphasizes the need for specific training to teach hybrid and online L2 courses, as it is considerably different from face-to-face language teaching (Compton, 2009; Ernest \& Hopkins, 2006; Gallardo, Heiser, \& Nicolson, 2011b; Goertler, 2011; Hampel \& Stickler, 2005; Hauck \& Stickler, 2006; Jones \& Youngs, 2006; Kessler, 2006; Lewis, 2006; Murphy, Shelley, White, \& Baumann, 2011; Sánchez-Serrano, 2008; Youngs, 2007). In a study examining instructor and student perspectives on characteristics of effective online language teachers, Murphy et al. (2011) distinguished eight broad categories based on survey responses from teachers and students involved in online language classes at the Open University in the UK. The authors suggested this information could provide a useful framework when training instructors to teach online language classes. The following list highlights necessary attributes in each of the eight categories for online language instructors:

1. Personal qualities (e.g., enthusiastic, approachable, supportive, committed)

2. Knowledge of the university system and distance learning (e.g., know the course materials well, know what is expected of students for assignments and exams and tell them)

3. One-to-one interpersonal and support skills (e.g., provide appropriate support, provide unambiguous, individualized, and prompt feedback using language at the appropriate level)

4. Group support and management (e.g., establish a friendly and supportive atmosphere, design tutorial activities where student involvement predominates)

5. Subject matter expertise (e.g., have native or near-native speaker competency, understand how learners learn grammar)

6. Teaching expertise (e.g., differentiate/provide for a variety of needs, give examples, assist development of pronunciation)

7. Organization (e.g., be organized with records/materials, respond promptly to student queries) 
8. Information technology skills (e.g., have computer literacy skills, use email for communication with learners and institution, be aware of relevant resources).

(Murphy et al., 2011, pp. 403-404)

Some researchers have found that $\mathrm{L} 2$ teachers and students have differing opinions of what constitutes effective language teaching. This, in turn, can lead to students feeling dissatisfied with the language class and possibly discontinuing language studies (Horwitz, 1990; Kern, 1995; Schulz, 1996). Brown (2009) investigated students' and teachers' perceptions of effective foreign language teaching by surveying students and teachers from first and second year language classes at the University of Arizona. Survey participants included students and teachers in 49 of 83 intact classes across nine languages. Results showed that students seemed to prefer a grammar-based approach, whereas most teachers favored communicative methods; significant differences also occured in areas such as target language use, error correction, and group work. Brown (2009) concluded that these differences demonstrate that $L 2$ teachers need to actively elicit students' perspectives and "engage them in brief classroom discussions about the rationale behind certain instructional strategies" (p. 46). Other researchers have offered similar recommendations (e.g., Kern, 1995; Murphy et al., 2011). These discussions and mutual understandings are also important in computer-mediated contexts: instructors and students both need to believe it is possible to learn languages in online or hybrid environments, if either group is to fulfill its role successfully (Blake, 2014; Murphy et al., 2011). In particular, in a hybrid or online class, students have to accept considerably more responsibility for their own learning to be successful (Blake, 2011, 2014).

Teachers need to use more learner-centered methods to help students develop communicative skills when there are limited or no face-to-face or synchronous meetings (Jones \& Youngs, 2006; Jones et al., 2007; Murphy et al., 2011; Youngs, 2007). It can be challenging to use learner-centered methods when students are accustomed to and expect teacher-centered instruction (Brown, 2009; Lewis \& Reinders, 2007). Teachers can, however, provide scaffolding to help students gradually develop learner autonomy (e.g., Lewis \& Reinders, 2007). Teaching methodology also needs to be adapted significantly for hybrid learning environments (Reynard, 2007; Youngs, 2007).

Research has shown various types of knowledge are necessary to be a good instructor. For instructors who are learning to effectively integrate technology into their teaching, important areas include technological, pedagogical, and content knowledge, also known as TPACK (Mishra \& Koehler, 2006). By using technology in ways similar to what they request of their students, teachers can gain experiences that help them to understand what their students are going through as well as how to use technology more effectively for teaching (Bustamante \& Moeller, 2013; Murphy et al., 2011). Teachers and students may know how to use a given technology, but using it for educational purposes and in the target language can be more challenging and therefore necessitate training (Goertler, Bollen, \& Gaff, 2012; Rubio \& Thoms, 2014a). Explanations and tutorials can be helpful, but in some cases hands-on training may be more efficient. For these reasons, 
researchers recommend integrating suitable hands-on activities when training teachers to use technology with their own students. While training instructors to teach hybrid courses often focuses on how to use technology, it is more important to study how pedagogical strategies need to be adapted to provide an effective learning environment for students in limited face-to-face sessions and activities outside of class (Reynard, 2007).

A basic tool to encourage the exchange of ideas is by using asynchronous computermediated communication on discussion boards. They offer a place where teachers can share ideas and reflections, as well as solve problems (Arnold \& Ducate, 2006). Researchers recommend taking advantage of affordances of these and similar tools as they provide a convenient channel for ongoing communication and information sharing (Arnold, Ducate, Lomicka, \& Lord, 2005; Arnold \& Ducate, 2006; Ernest \& Hopkins, 2006). Allowing teachers the opportunity to use technological tools themselves before teaching with them can help them gain confidence (Arnold \& Ducate, 2006; Bustamante \& Moeller, 2013; Gallardo et al., 2011b; Murphy et al., 2011). Arnold and Ducate (2006) found discussion boards to be useful for professional development of new and future teachers due to "their potential to promote social interaction and cognitive growth" ( $p$. 42).

Another useful tool to organize information and facilitate communication for online learning is an online course management system (CMS), such as Angel, Blackboard, Canvas, D2L, Moodle, and Sakai. Teachers surveyed in Ernest and Hopkins (2006) explained how their CMS was very useful for professional development, materials sharing, and communication purposes in their institution. Ideally, professional development would be based in the same CMS the teachers will be using for their teaching. Another option is to use an open-source CMS such as Moodle. A CMS can be used as a one-stopshop to share and archive materials, post information, and exchange ideas. Moodle, for example, is free, popular, easy to use, offers many tools, and can send users email updates for items posted in its news forums.

Discussion boards can be valuable to enable communication between teachers and for professional development. Similarly, they have potential value to encourage communication among students and instructors in class. For example, teachers can encourage students to post questions and respond to each other on the discussion board to reduce the number of student-teacher emails and to encourage students to exchange ideas. Teachers have found online discussion boards to be useful both in dealing with students' questions (e.g., Bustamante \& Moeller, 2013; Ko \& Rossen, 2010; Murphy et al., 2011) and as tools for building a sense of community among groups of students (Arnold \& Ducate, 2006). In a class with reduced face-to-face meetings, it is challenging to build community, but important (Goertler, 2014).

Another useful way to train new hybrid or online teachers is to ask instructors with recent experience teaching these courses what advice they would offer to new teachers (Murphy et al., 2011). Matching up new teachers with mentors has shown to be very 
helpful (Gallardo, Heiser, \& Nicolson, 2011a; Leaver \& Oxford, 2001; Melin, 2000; Siskin \& Davis, 2001). Providing clear guidelines for mentors to offer support to new teachers proactively has proven to be a very effective means of helping new online teachers at the Open University (see Gallardo et al., 2011b, p. 234 for useful guidelines). Although these could be set up formally at the beginning of each semester, sharing information informally should be encouraged on an ongoing basis. Peer observation, occasional workshops, and shared resource banks are also recommended as they have shown to be helpful (Gallardo et al., 2011b).

Reflection is helpful in teacher development; thus, Wildner-Bassett (1993) recommends asking teachers to write learning logs. Selected critical incidents may then be submitted to the teacher trainer for feedback. In addition, new teachers could be encouraged to share selected challenges and ask for feedback from peers, either face to face, or online. Several teacher educators with extensive experience in preparing teachers for online and hybrid $\mathrm{L} 2$ teaching recommend that supervisors also meet individually with the new teachers (Gallardo et al., 2011b; Jones \& Youngs, 2006). Having this one-on-one meeting early in the first semester of teaching can ensure that new teachers are on track and provide scaffolding where necessary.

As Rankin and Becker (2006) pointed out, "A model of teacher development based on knowledge transmission is, at its core, profoundly inadequate" (p. 366). In other words, just telling new teachers what to do or having them read articles is not sufficient. Instead, teachers need to consider their own beliefs about language teaching and learning, develop their personal philosophy of teaching, reflect, observe others, be observed, exchange ideas, explore doubts, develop goals, and plan for ongoing professional development.

\section{Suggested Model for Professional Development of New Hybrid or Online L2 Teachers}

Ideally, instructors who are going to teach hybrid or online classes choose to do so because it does require learning different skills and relies more significantly on technology and advanced planning than traditional face-to-face teaching. The Professional Development Model for Online Course Development (Hinson \& LaPrairie, 2005) inspired a five-step plan that will be presented in this paper. It was originally created to help college instructors transition from teaching traditional face-to-face classes to teaching online. When providing professional development for teachers with no prior teaching experience, additional topically-related training will be necessary. Since experiencing learning through technology can help teachers empathize with their students and learn by doing, the instructional technology itself should be strategically used in professional development whenever possible.

A hybrid model including a combination of face-to-face meetings about once a month is recommended, if possible, combined with an online discussion board for asynchronous communication and materials sharing. Online components should ideally be on an easyto-use, well-organized course management system selected for long-term continuing conversations and sharing materials. Face-to-face meetings encourage community 
building and open communication, which is critical especially for new teachers. If faceto-face meetings are not possible, synchronous online meetings are recommended, although these may lead to qualitatively different experiences and extra precautions would be needed to avoid and to deal with technology issues. Each of the five proposed (sometimes overlapping) stages and recommendations for each stage are explained below.

1. Planning:

Planning and preparation, especially before the semester begins, are critical to help new teachers be ready and to start the semester off well. First impressions are important: do your best to provide clear information on the first day of class and/or the first time students log on to the course website. It is helpful to allow students to access the online course and syllabus a week before class starts so that they can familiarize themselves with the online environment and course. Students should be invited to go ahead and respond to an introductory discussion board prompt and respond to at least two other students to start building community. At least one week before classes start (earlier if possible) there should be training for the new teachers, preferably face-toface, which should include general information sessions with all L2 teachers in the department, followed by specific meetings tailored to new teachers: those who will be teaching hybrid or online courses, as well as sessions for teachers that will be teaching the same level. Teachers should be introduced to the course website and teaching materials, the online discussion board for communicating with the other teachers, and any other necessary resources.

a. Provide teachers with a checklist of what they need to do and know before the first day of class (e.g., how to use the course website to do necessary tasks, as well as how to check what students do online and give feedback).

b. Conduct a needs assessment with new teachers to help identify concerns and set objectives. This can be done in the first language or the target language and could be done anonymously to encourage new teachers to share their concerns.

c. Invite experienced online or hybrid teachers to share their recommendations with new teachers. (e.g., "If I had known then what I know now...")

d. Match up new teachers with a mentor. Provide mentors with clear guidelines and encourage them to be proactive to help new teachers, who may often be hesitant.

e. Have teachers work with others teaching at the same level and/or in the same medium (i.e., hybrid or online), to share ideas and start creating lesson plans. The initial meeting with guidelines can be with the teacher trainer, at which time teachers can briefly present their plans. Later, teachers can 
meet on their own and/or can collaborate using a tool like Google Docs. Teachers should be encouraged to share strategies and plan cooperatively for effective instruction and materials development following researchbased recommendations.

f. Teachers learn how to use technology that is necessary to teach their course effectively by watching tutorials and trying out the technology.

2. Instruction:

Various aspects of planning will continue throughout the semester.

Teachers should plan face-to-face and synchronous meetings with students carefully, making sure there is a clear connection with what students do in class and outside of class. Teachers should also be encouraged to share ideas with colleagues.

3. Implementation:

a. Teachers should diligently check the course website to review what students are assigned to do, see what they are actually doing and where they are having problems, as well as address questions, notice common errors, and plan how to address student problems. Teachers will need need to help train students how to be effective in the hybrid or online class environment (e.g., using metacognitive strategies and expending adequate time on task).

b. Teachers should meet with their mentors and/or supervisors to review record-keeping, grading, feedback, online activity tracking, lesson/courseplanning and reflections on teaching activities.

c. Teachers should observe both more experienced colleagues and those teaching at the same level, as well as invite class observation by their colleagues. These observations may lead to discussion of concerns and advice on how to make improvements. Teachers should also be encouraged to keep a reflective journal and to share some reflections at various points over the course of the academic term.

\section{Refinement:}

Around mid-semester, there should be a needs analysis to encourage teachers to reflect on how they are doing and in what instructional areas they might improve. They should also be encouraged to ask their students to fill out an anonymous feedback survey while there is still time to make adjustments. 
5. Evaluation:

At the end of the semester, teachers may respond to an anonymous survey regarding the professional development program during the semester and offer suggestions for improving it.

Between the monthly meetings, teachers should be encouraged to communicate openly with their mentors and fellow teachers, either in person and/or via (synchronous) computer-mediated communication to share materials, exchange ideas and address issues that arise. Several other professional development activities may also be useful, but if new teachers are currently enrolled in a teacher-training program, care should be taken not to replicate what they are doing there, and to address issues that are specific to technology-enhanced language teaching. Some useful activities could be:

- Describe an ideal hybrid or online L2 teacher.

- Choose a metaphor for teaching and explain it.

- Write a philosophy of teaching and give examples of ways to facilitate learning and create community in a hybrid or online environment.

- Video record yourself teaching class, watch the recording, reflect on strengths and weaknesses, and plan for improvement.

- Discuss any or all of the activities above with your supervisor and/or mentor.

\section{Conclusion and Suggestions for Further Reading}

Developing new hybrid or online courses is challenging and time-consuming, but each subsequent course does get easier. Instructional designers recommend using the ADDIE model when creating and refining materials; this model includes the following five stages: analysis, design, development, implementation, and evaluation. Teaching online and hybrid courses is a dynamic, iterative process that requires ongoing refinement. Materials and instructional methods need to be continually re-examined and adjusted to ensure that they are helping students meet the desired learning outcomes as well as meeting the students' own needs. Institutions should not view online and hybrid (language) classes as a way to save money. Instead, technology should be used to offer learning affordances, such as enabling access to authentic multi-media materials and providing more opportunities for interaction and time on task. Computer-assisted language learning (CALL) also has other benefits including immediate feedback for some types of exercises, more time and opportunities to participate, and greater control over learning, all of which can help motivate learners and facilitate language development.

Many foreign language departments are currently required to offer online and hybrid courses. This article focused on preparing instructors to teach online and/or hybrid courses that have already been developed. For instructional designers working to 
develop these courses, it is important to follow guidelines of effective practice such as the Quality Matters rubric (2014) and the Community of Inquiry model (Garrison, Anderson, \& Archer, 2000). The latter has been used by researchers to analyze course implementation and includes three elements: cognitive, social, and teaching presence. In addition, there are organizations dedicated to providing guidance on online instruction such as the Online Learning Consortium, which also offers conferences, webinars, and an online journal (see http://onlinelearningconsortium.org/about/olc-2/).

While some guidelines and instructional design principles are general and apply to teaching any subject, it is also important to include training specific to language teaching and to consider research findings in CALL and second language acquisition (SLA). Organizations dedicated to the professional development of language teachers can also provide important resources: for example Teachers of English to Speakers of Other Languages (TESOL) supports instructors involved in English language teaching; one of its interest sections focuses on CALL. TESOL also holds an Electronic Village at its international convention and Electronic Village Online each year, both of which provide hands-on experience (see http://www.tesol.org/connect/interest-sections/computer-assistedlanguage-learning). The American Council on the Teaching of Foreign Languages (ACTFL) conference also provides a growing number of presentations related to technology and has a Distance Learning special interest group that addresses challenges many distance learning educators face (http://www.actfl.org/membership/special-interest-groups-sigs/ distance-learning). The Computer-Assisted Language Instruction Consortium (CALICO) is dedicated to the research and development of technology for language learning and teaching (https://calico.org). CALICO holds an annual conference in North America and publishes an annual volume focusing on current themes in the field as well as CALICO Journal, which focuses on research in technology-enhanced language learning. Language Learning \& Technology is another refereed journal that publishes research on topics related to technology and language education (http://llt.msu.edu).

In addition, there are a number of recent books by leading researchers in online language teacher education, for example Teaching Languages Online (Meskill \& Anthony, 2015) and Developing Online Language Teaching: Research-Based Pedagogies and Reflective Practices (Hampel \& Stickler, 2015). An increasing number of universities and organizations are also offering training to provide preparation to design and deliver language courses online. For example, TESOL offers several courses (see http://www.tesol.org/eventslanding-page/2016/01/18/default-calendar/pp-100-certificate-foundation-course). The University of Arizona has a new online Master's program in Second Language Learning and Educational Technology (see http://uaonline.arizona.edu/program/second-languagelearning-educational-technology-ma). To summarize: although teaching courses that are partially or fully online brings new challenges, resources are expanding to provide scaffolding that can help meet the needs of those who teach in these technology-rich environments. 


\section{References}

Allen, H. W., \& Negueruela-Azarola, E. (2010). The professional development of future professors of foreign languages: Looking back, looking forward. The Modern Language Journal, 94(3), 377-395. doi:10.1111/j.1540-4781.2010.01056.x

Arnold, N., \& Ducate, L. (2006). Future foreign language teachers' social and cognitive collaboration in an online environment. Language Learning \& Technology, 10(1), 42-66.

Arnold, N., Ducate, L., Lomicka, L., \& Lord, G. (2005). Using computer-mediated communication to establish social and supportive environments in teacher education. CALICO Journal, 22(3), 537-566.

Blake, R. J. (2011). What makes an ideal hybrid language learner? Retrieved from http://blc.berkeley.edu/index.php/blc/post/lecture_march_18/

Blake, R. J. (2014). Best practices in online learning: Is it for everyone? In F. Rubio \& J. Thoms (Eds.), Hybrid language teaching and learning: Exploring theoretical, pedagogical and curricular issues (pp. 10-26). Boston, MA: Heinle Cengage.

Brown, A. V. (2009). Students' and teachers' perceptions of effective foreign language teaching: A comparison of ideals. The Modern Language Journal, 93(i), 46-60. http://doi.wiley.com/10.1111/j.1540-4781.2009.00827.x

Bustamante, C., \& Moeller, A. (2013). The convergence of content, pedagogy, and technology in online professional development for teachers of German: An intrinsic case study. CALICO Journal, 30(1), 82-104. doi:10.11139/cj.30.1.82104

Compton, L. K. L. (2009). Preparing language teachers to teach language online: a look at skills, roles, and responsibilities. Computer Assisted Language Learning, 22(1), 73-99. doi:10.1080/09588220802613831

Ernest, P., \& Hopkins, J. (2006). Coordination and teacher development in an online learning environment. CALICO Journal, 23(3), 551-568.

Gallardo, M., Heiser, S., \& Nicolson, M. (2011a). Practical approaches for teacher development. In M. Nicolson, L. Murphy, \& M. Southgate (Eds.), Language teaching in blended contexts (pp. 232-245). Edinburgh: Dunedin Academic Press.

Gallardo, M., Heiser, S., \& Nicolson, M. (2011b). Teacher Development for Blended Contexts. In M. Nicolson, L. Murphy, \& M. Southgate (Eds.), Language teaching in blended contexts (pp. 219-231). Edinburgh: Dunedin Academic Press. 
Garrison, D. R., Anderson, T., \& Archer, W. (2000). Critical inquiry in a text-based environment: Computer conferencing in higher education. The Internet and Higher Education, 2(2-3), 87-105.

Goertler, S. (2011). Blended and open/online learning: Adapting to a changing world of foreign language teaching. In N. Arnold \& L. Ducate (Eds.), Present and future promises of CALL: From theory and research to new directions in language teaching (pp. 471-501). San Marcos, TX: CALICO.

Goertler, S. (2014). Theoretical and empirical foundations for blended language learning. In F. Rubio \& J. Thoms (Eds.), Hybrid language teaching and learning: Exploring theoretical, pedagogical and curricular issues (pp. 27-49). Boston, MA: Heinle Cengage.

Goertler, S., Bollen, M., \& Gaff, J. (2012). Students' readiness for and attitudes toward hybrid FL instruction. CALICO Journal, 29(2), 297-320.

Hampel, R., \& Stickler, U. (2005). New skills for new classrooms: Training tutors to teach languages online. Computer Assisted Language Learning, 18(4), 311-326. doi:10.1080/09588220500335455

Hampel, R., \& Stickler, U. (2015). Developing online language teaching: Research-based pedagogies and reflective practices, NY: Palgrave Macmillan.

Hauck, M., \& Stickler, U. (2006). What does it take to teach online? CALICO Journal, 23(3), 463-475.

Hinson, J. M., \& LaPrairie, K. N. (2005). Learning to teach online: Promoting success through professional development. Community College Journal of Research and Practice, 29, 483-493.

Horwitz, E. K. (1990). Attending to the affective domain in the foreign language classroom. In S. Magnan (Ed.), Shifting the instructional focus to the learner (pp. 15-33). Middlebury, VT: Northeast Conference on the Teaching of Foreign Languages.

Jones, C. M., Queuniet, S., Youngs, B., Allen, H., Wells, B., Campbell, C., \& Lawrence, J. (2007). French Online instructor's manual. Pittsburgh, PA: Carnegie Mellon University. Retrieved from http://ml.hss.cmu.edu/frenchonline/index.html

Jones, C. M., \& Youngs, B. L. (2006). Teacher preparation for online language instruction. In P. Hubbard \& M. Levy (Eds.), Teacher education in CALL (pp. 267280). Philadelphia, PA: John Benjamins.

Kern, R. G. (1995). Students' and teachers' beliefs about language learning. Foreign Language Annals, 28(1), 71-92. 
Kessler, G. (2006). Assessing CALL teacher training: What are we doing and what could we do better? In P. Hubbard \& M. Levy (Eds.), Teacher education in CALL (pp. 23-42). Philadelphia, PA: John Benjamins.

Ko, S., \& Rossen, S. (2010). Teaching online: A practical guide (3rd ed.). New York, NY: Routledge.

Leaver, B. L., \& Oxford, R. (2001). Mentoring in style: Using style information to enhance mentoring of foreign language teachers. In B. Rifkin (Ed.), Mentoring foreign language teaching assistants, lecturers, and adjunct faculty. Issues in language program direction: A series of annual volumes (pp. 55-88). Boston, MA: Heinle.

Lewis, M., \& Reinders, H. (2007). Developing learner autonomy. In Using studentcentered methods with teacher-centered students (2nd ed.). Toronto: Pippin Publishing.

Lewis, T. (2006). When teaching is learning: A personal account of learning to teach online. CALICO Journal, 23(3), 581-600.

Melin, C. (2000). Beyond language courses and into the college classroom: TAs and the full scope of undergraduate teaching. Die Unterrichtspraxis, 33, 7-13.

Meskill, C., \& Anthony, N. (2015). Teaching languages online (2nd ed.). Buffalo, NY: Multilingual Matters.

Mishra, P., \& Koehler, M. J. (2006). Technological pedagogical content knowledge: a framework for teacher knowledge. Teachers College Record, 108(6), 1017-1054. doi:10.1111/j.1467-9620.2006.00684.x

Murphy, L. M., Shelley, M. A., White, C. J., \& Baumann, U. (2011). Tutor and student perceptions of what makes an effective distance language teacher. Distance Education, 32(3), 397-419. doi:10.1080/01587919.2011.610290

Quality Matters Higher Education rubric. (2014). Retrieved from https://www. qualitymatters.org/rubric

Rankin, J., \& Becker, F. (2006). Does reading the research make a difference? A case study of teacher growth in FL German. The Modern Language Journal, 90(iii), 353-372.

Reynard, R. (2007). Hybrid learning: Challenges for teachers. T.H.E. Journal. Retrieved from http://thejournal.com/articles/2007/05/17/hybrid-learning-challenges-forteachers.aspx

Rubio, F., \& Thoms, J. (2014a). Hybrid language teaching and learning: Exploring theoretical, pedagogical and curricular issues. Boston, MA: Heinle Cengage. 
Rubio, F., \& Thoms, J. (2014b). Hybrid language teaching and learning: Looking forward. In F. Rubio \& J. Thoms (Eds.), Hybrid language teaching and learning: Exploring theoretical, pedagogical and curricular issues (pp. 1-9). Boston, MA: Heinle Cengage.

Sánchez-Serrano, L. (2008). Initiation by fire: Training teachers for distance learning. In S. Goertler \& P. Winke (Eds.), Opening doors through distance language education: Principles, perspectives, and practices (pp. 153-174). San Marcos, TX: CALICO.

Schulz, R. A. (1996). Focus on form in the foreign language classroom: Students' and teachers' views on error correction and the role of grammar. Foreign Language Annals, 29, 343-364.

Siskin, H. J., \& Davis, J. (2001). Historical, theoretical, and pragmatic perspectives on mentoring. In B. Rifkin (Ed.), Mentoring foreign language teaching assistants, lecturers, and adjunct faculty. Issues in language program direction: A series of annual volumes (pp. 1-17). Boston: Heinle.

Wildner-Bassett, M. E. (1993). "Poof! You're a teacher!": Using introspective data in the professional development of beginning TAs. In J. C. Walz (Ed.), Development and supervision of teaching assistants in foreign languages. Issues in language program direction: A series of annual volumes (pp. 153-169). Boston: Heinle.

Youngs, B. (2007). Teaching teachers: Methodological questions for the online environment. In M. A. Kassen, R. Z. Lavine, K. Murphy-Judy, \& M. Peters (Eds.), Preparing and developing technology-proficient L2 teachers (pp. 67-90). San Marcos, TX: CALICO. 